\title{
SEJARAH PONDOK PESANTREN AL FALAH GEDONGAN, BAKI, SUKOHARJO, JAWA TENGAH (2006-2018)
}

Adib Abbiya Qowiyyudin

Fakultas Adab dan Ilmu Budaya UIN Sunan Kalijaga Yogyakarta

$\backslash$ adibabbiya82@gmail.com

Abstrak

Pesantren merupakan subkultur Islam yang mengakar pada kebudayaan Islam di Indonesia. Pendidikan di pesantren, tidak hanya identik dengan sarana dan praktik pendidikan, tetapi juga penanaman sejumlah nilai dan karakter moral. Berdirinya Pondok Pesantren Al Falah memberikan dampak sosial keagamaan bagi masyarakat serta menjadi pusat kajian Islam di wilayah Gedongan, Baki, Sukoharjo. Pendekatan yang digunakan oleh peneliti yaitu Sosiologi budaya. Pendekatan Sosiologi Budaya mengkaji tentang konsep dan perilaku msyarakat yang mampu menafsirkan dan memecahkan fenomena budaya dalam sudut pandang sosiologi. Teori yang digunakan dalam penelitian ini yaitu teori fungsional struktural yang dikemukakan oleh Robert K Merton. Metode yang digunakan yaitu metode sejarah, yang meliputi empat langkah yaitu heuristik, verifikasi, interpretasi dan historiografi.

Kata Kunci: Pesantren Al-Falah, Subkultur Islam, Masyarakat Desa Gedongan

Abstract

Pesantren is an Islamic subculture rooted in Islamic culture in Indonesia. Education in pesantren is not only synonymous with educational facilities and practices, but also the inculcation of a number of moral values and characters. The establishment of the Al Falah Islamic Boarding School had a socio-religious impact on the community and became a centre for Islamic studies in the Gedongan area, Baki, Sukoharjo. The approach used by researchers in cultural sociology. The Cultural Sociology approach examines the concepts and behaviour of people who are able to interpret and solve cultural phenomena from a sociological point of view. The theory used in this research is the structural-functional theory proposed by Robert K Merton. The method used is the historical method, which includes four steps, namely heuristics, verification, interpretation and historiography.

Keywords: Islamic Boarding School, islamic subculture, Gedongan Village Community

\section{Pendahuluan}

Pesantren merupakan akar dari perkembangan sistem pendidikan nasional.

Dari segi historis pesantren tidak hanya identik dengan makna keislaman, tetapi juga mengandung makna keaslian Indonesia (indigenous) (Nurcholis Madjid, 1997:

3). Pesantren merupakan pusat spiritual dan intelektual masyarakat, dari sini 
timbul dorongan yang beraneka ragam untuk menggerakan penduduk sekitar wilayah berkontribusi dalam kegiatan di pesantren (Manfred Ziemek, 1986: 19). Lembaga pendidikan Islam yang merupakan pelopor modernisasi pendidikan di Jawa Tengah khususnya di wilayah Kabupaten Sukoharjo yaitu Pondok Pesantren Al Falah Gedongan, Baki, Sukoharjo.

Menurut Zamakhsyari Dhofier, kiai merupakan elemen penting dari suatu pesantren, ia merupakan pendiri pesantren. Sudah sewajarnya bahwa pertumbuhan suatu pesantren bergantung kepada kemampuan pribadi kyainya sendiri (Zamakhsyari Dhofier, 1982: 55). Hal itu dapat terjadi secara sosiologis keagamaan, bahwa masyarakat cenderung mengikuti dan melaksanakan kebijakan kyai dari pesantren. Seiring dengan perkembangannya pesantren harus mampu mengadaptasi dirinya dengan alam global, yang ditandai dengan adanya perubahanperubahan struktural dalam seluruh kehidupan bangsa yang mempengaruhi segala aspek kehidupan sesuai tuntunan zaman.

Pondok Pesantren Al Falah terletak di Desa Gedongan, Kecamatan Baki, Kabupaten Sukoharjo. Didirikan pada tanggal 2 November 2006 dan sudah mendapatkan Ijin Operasional Pondok berdasarkan Keputusan Kepala Kantor Kementerian Agama Kabupaten Sukoharjo dengan tujuan untuk membantu pemerintah memenuhi kebutuhan masyarakat di bidang pendidikan dasar dan keagamaan sekaligus sebagai sarana dakwah dalam rangka mewujudkan generasi Islam yang unggul dalam prestasi berdasarkan ilmu pengetahuan dan teknologi, iman dan taqwa untuk menuju masyarakat madani.

Pondok Pesantren Al Falah merupakan pondok pesantren yang menganut sistem modern. Pondok pesantren modern merupakan pondok pesantren yang memiliki lembaga formal untuk mendidik santri dalam mata pelajaran umum dan agama. Pondok pesantren modern tidak hanya fokus terhadap kitab kuning saja, tetapi mengajarkan pendidikan formal sesuai dengan kurikulum yang diterapkan oleh pemerintah dengan alasan saat ini santri harus mampu bersaing dan menguasai ilmu umum dan agama.

Di era globalisasi seperti saat ini kemampuan masyarakat tradisional dalam mempertahankan kebudayaan lokal menjadi sebuah perjuangan yang sangat berat 
karena, kesenian tradisonal sudah diubah oleh kebudayaan modern yang semakin tinggi eksistensinya dan digemari oleh orang banyak. Dalam hal ini, Pondok Pesantren Al Falah memiliki kegiatan ekstrakulikuler kesenian Jawa berupa Karawitan dan Wayang. Santri ikut berpartisipasi dalam kegiatan tersebut guna melestarikan budaya tradisional yang semakin punah dan dipadukan dengan dakwah Islam melalui alur cerita wayang dan disaksikan oleh masyarakat sekitar yang ikut berkontribusi dalam kegiatan rutin.

Selain itu, tujuan adanya ekstrakulikuler kesenian Jawa di pondok pesantren yaitu mencegah radikalisme dan kenakalan remaja yang saat ini sering terjadi di lingkungan sekitar pondok pesantren dan masyarakat umum. Melalui kajian tentang tembang dolanan dan tembang lain yang dijelaskan oleh kiai, masyarakat dapat mengambil dan diamalkan dalam kehidupan sehari-hari. Sering mengikuti kegiatan lomba macapat di tingkat Kelurahan, Kecamatan, Kabupaten, Nasional dan tampil dalam kegiatan keagamaan seperti Maulid Nabi, Isya' Mi'raj dan lain sebagainya.

Berdasarkan latar belakang masalah di atas, maka peneliti tertarik untuk meneliti Pondok Pesantren Al Falah Gedongan, Baki, Sukoharjo karena salah satu pondok pesantren yang berbasis kebudayaan melalui kesenian wayang dan kesenian karawitan yang berkaitan dengan Ilmu agama. Dalam hal ini santri berperan aktif dalam memainkan alat musik gamelan dan wayang kulit, masyarakat ikut serta dalam kegiatan dakwah Islam melalui kebudayaan yang dilestarikan oleh santri.

Hubungan dan kerjasama masyarakat dengan pesantren meliputi segala aspek kehidupan yang saling mempengaruhi, bekerjasama sehingga secara langsung berkontribusi terhadap segala aktifitas. Selain itu sarana dan prasarana berkembang pesat dimulai dari pembangunan lingkungan sekitar yang dapat menunjang kegiatan sehingga masyarakat mulai tertarik dengan kegiatan yang dilaksanakan di pondok pesantren.

\section{Metode Penelitian}


Penelitian mengenai Sejarah Pondok Pesantren Al Falah Gedongan, Baki, Sukoharjo Jawa Tengah (2006-2018) ini menggunakan pendekatan sosiologi budaya. Pendekatan sosiologi budaya merupakan suatu keseluruhan dari unsurunsur tata nilai, tata sosial, dan tata laku manusia yang saling berkaitan dan masingmasing unsur bekerja secara mandiri serta bersama-sama satu sama lain saling mendukung untuk mencapai tujuan hidup manusia dalam masyarakat (Jacobus Ranjabar, 2013: 17-18). Pendekatan sosiologi budaya digunakan untuk membantu peneliti dalam mendiskripsikan dan menganalisis berkaitan dengan sejarah Pondok Pesantren Al Falah Gedongan, Baki, Sukoharjo. Pendekatan sosiologi budaya menjadi acuan untuk membantu peneliti dalam menjawab rumusan masalah dan menghubungkan fakta yang terjadi di masyarakat seperti dukungan secara penuh terhadap berdirinya Pondok Pesantren Al Falah.

Teori yang digunakan untuk menganalisis tentang Sejarah Pondok Pesantren Al Falah Gedongan, Baki, Sukoharjo, Jawa Tengah (2006-2018) adalah teori Fungsional Struktural. Teori fungsional struktural yaitu suatu masyarakat dilihat sebagai suatu jaringan kelompok yang bekerjasama secara terorganisasi yang bekerja dalam suatu cara yang agak teratur menurut seperangkat peraturan dan nilai yang dianut oleh sebagian besar masyarakat tersebut.

Menurut Robert K Merton analisis struktural fungsional ini memusatkan perhatiannya pada suatu kelompok, organisasi, masyarakat dankultur. Menurutnya, sasaran studi struktural fungsional ini antara lain, peran sosial ke masyarakat melalui pola institusional. Proses sosial dalam hubungan antara pondok pesantren melalui pola kultur dan aturan yang diterapkan di pondok pesantren serta pengendalian (Paul B. Horton dan Chester L Hunt, 1996: 18). Teori fungsional struktural membantu dalam menemukan fakta setelah menemukan berbagai sumber yang telah dikumpulkan oleh peneliti, kemudian diperjelas dan dipertajam berkaitan dengan sejarah berdiri Pondok Pesantren Al Falah dibantu masyarakat dalam mengembangkan pondok pesantren.

Peneliti memperoleh sumber data melalui empat tahap sebagai berikut:

1. Heuristik 
Heuristik yaitu proses pengumpulan data yang ada kaitannya dengan pokok persoalan yang diteliti (Kuntowijoyo, 1995: 95). Peneliti mencari dan menemukan sumber-sumber berupa arsip yang berkaitan dengan sejarah perkembangan pondok pesantren seperti surat resmi pengesahan pondok pesantren dan foto kegiatan dokumen dan data statistik pondok. Digunakan juga hasil wawancara dari pelaku dan saksi peristiwa. Selain itu juga ada sumber yang berupa benda misalnya bangunan pesantren, madrasah, masjid, dan lain sebagainya. Sumber sekunder berupa skripsi, tesis, disertasi dan buku-buku pendukung yang berkaitan dengan sejarah pondok pesantren.

Dalam mencari sumber tersebut peneliti menelusuri berbagai perpustakaan di antaranya, Perpustakaan Pusat UIN Sunan Kalijaga Yogyakarta, Perpustakaan Fakultas Adab dan Ilmu Budaya, Perpustakaan IAIN Surakarta, Perpustakaan Universitas Muhammadiyah Surakarta, Perpustakaan Universitas Negeri Sebelas Maret Surakarta, Perpustakaan Pondok Pesantren Al Falah Gedongan, Baki, Sukoharjo, Pusat Layanan Pondok Pesantren Al Falah Gedongan, Baki, Sukoharjo.

Metode wawancara peneliti mengumpulkan data melalui wawancara secara langsung seperti pengelola, pendiri dan masyarakat umum yang lebih mengetahui sejarah berdirinya Pondok Pesantren Al Falah serta mengetahui kondisi sebelum dan sesudah berdirinya pondok pesantren. Wawancara ini dilakukan untuk mengumpulkan data yang berkaitan dengan sejarah Pondok Pesantren Al Falah, hubungan dengan masyarakat dan berkaitan dengan tujuan penelitian. Peneliti menemukan data tertulis berupa arsip, dan dokumen yang diperoleh dari pengurus Pondok Pesantren Al Falah. Tujuan metode ini untuk mendapat gambaran dan data yang spesifik sehingga mendapatkan data yang detail dan sesuai fakta.

\section{Verifikasi}

Kritik sumber merupakan tahap penelitian sejarah setelah mengumpulkan data. Kritik sumber adalah pengujian sumber-sumber sejarah, pengujian ini bertujuan untuk mengetahui tingkat otentitas (keaslian sumber) dan tingkat kredibilitas (bisa dipercaya) sumber tersebut (Kuntowijoyo, 1995: 100). Selain itu, peneliti menguji hasil wawancara dan melakukan perbandingan hasil wawancara dari narasumber satu dengan narasumber lain yang terlibat secara langsung proses 
berdirinya Pondok Pesantren Al Falah. Seperti contoh ketika peneliti melakukan wawancara dengan Bapak Muh Fajar Syaifuddin tentang sejarah berdirinya Pondok Pesantren Al Falah, peneliti membandingkan dengan narasumber lain yaitu salah satu warga yang tinggal di sekitar pondok pesantren yaitu Ibu Sri Marsiti juga menjadi saksi sejarah tentang berdiri dan berkembang Pondok Pesantren Al Falah.

\section{Interpretasi}

Interpretasi atau yang biasa dikenal dengan penafsiran sejarah merupakan tahapan penelitian yang paling penting dalam metode penelitian sejarah, karena di sinilah dipertaruhkan kemampuan peneliti sejarah. Interpretasi sendiri dibagi menjadi dua macam yaitu analisis yang berarti menguraikan dan sintesis yang berarti menyatukan (Basri, 2006:69). Peneliti ini dilakukan analisa terhadap proses historis yang terjadi dari masa berdiri hingga berkembang pesat sampai tahun 2018. Interpretasi dilakukan untuk menghindari salah penafsiran terhadap proses masa berdiri hingga perkembangan pondok pesantren. Peneliti melakukan sintesis untuk memperoleh fakta yang detail secara obyektif, dipadukan dengan pendekatan sosiologi dan teori fungsional struktural oleh Robert K Merton.

\section{Historiografi}

Tahap historiografi yaitu proses penulisan kembali peristiwa masa lampau berdasarkan data-data yang sudah diperoleh dari sumber primer dan sekunder. Historiografi merupakan tahap akhir dalam penelitian sejarah, sebab dalam tahap ini sudah menggambarkan peristiwa masa lampau yang mengandung aspek kronologis, sehingga memberi kemudahan dan menjelaskan kepada penulis dan pembaca mengenai urutan waktunya (Sartono Kartodirdjo, 1992: 62).

\section{Hasil dan Pembahasan}

\section{A. Latar Belakang Berdirinya Pondok Pesantren Al Falah}

Gedongan merupakan salah satu Desa di Kecamatan Baki, Kabupaten Sukoharjo, Provinsi Jawa Tengah. Sebelah Utara Desa Jetis, Barat Desa Daleman, Timur Desa Mancasan dan Selatan Perbatasan Kecamatan Wonosari. Pondok Pesantren Al Falah berada di Jl. Merpati No 2A RT 03 dan RW 02 Desa Gedongan, 
Kecamatan Baki, Kabupaten Sukoharjo. Pondok pesantren ini terletak di tengah desa, iklim yang sejuk jauh dari polusi transportasi sehingga mendukung kegiatan proses belajar mengajar (Wawancara dengan Bapak Fajar (salah satu guru di Pesantren Al Falah Gedongan Baki Sukoharjo), di rumah Bapak Fajar Bakipandeyan, Baki Sukoharjo pada hari Rabu tanggal 07 Maret 2019).

Sebelum berdirinya Pondok Pesantren Al Falah mayoritas masyarakat beragama Islam dan sebagian beragama non muslim, kehidupan dan hubungan beragama di Desa Gedongan, Baki, Sukoharjo tergolong baik. Keadaan sekitar Gedongan yang saat itu kondisinya masih kering dengan nilai-nilai agama dan belum tampak syiar agama Islam dengan mendirikan pondok pesantren, yang bermula dari sebuah rumah joglo yang didirikan oleh Kiai Sri Setyo dan membuat gagasan pendirikan pondok pesantren untuk mengubah kehidupan keagamaan masyarakat di sekitar pondok pesantren.

Setelah berdiri Pondok Pesantren Al Falah, berbagai macam program yang ditawarkan oleh pengelola pondok pesantren kepada masyarakat seperti kegiatan pengurusan jenazah, kajian rutin tentang akhlak, tasawuf, sosial, kebudayaan. Kegiatan tersebut diselenggarakan setiap hari ba'da Maghrib hingga menjelang shalat Isya' di masjid yang telah didirikan oleh pengasuh pondok pesantren. Kegiatan lain meliputi Taman Pendidikan alQur'an bagi semua kalangan, mengadakan pelatihan pengurusan jenazah, pelatihan kepemimpinan dalam masyarakat untuk memimpin sebuah majelis dan kegiatan lain yang berkaitan dengan aspek keagamaan. Program yang diselenggarakan oleh pengurus pondok pesantren meningkatkan rasa peduli terhadap pola kehidupan beragama yang berada di lingkungan pesantren dan masyarakat.

Sebelum berdirinya Pondok Pesantren Al Falah, telah berdiri organisasi yang berkaitan dengan lembaga swadaya masyarakat guna menjalin hubungan silaturahmi antara warga. Namun, kepengurusan dan dinamika belum berjalan dan terstruktur dengan baik, perlu diadakan sosialisasi kegiatan keorganisasian yang diselenggarakan oleh pengurus pondok pesantren sehingga memudahkan masyarakat untuk mengurus sebuah lembaga atau organisasi yang diikuti. Kehidupan sosial masyarakat Desa Gedongan tidak jauh berbeda dengan kehidupan 
sosial desa pada umumnya. Mereka menjalankan kehidupan sehari-hari dengan sifat gotong royong yang cukup kental. Dalam berbagai kegiatan, biasanya dikerjakan secara bersama-sama dan banyak melibatkan warga lain untuk membantu kegiatan sehari-hari (Wawancara dengan Ibu Sri Marsiti salah satu warga Gedongan, Baki Sukoharjo pada hari Ahad, 07 April 2019. Pukul 12:30 WIB).

Masyarakat Desa Gedongan dikenal sebagai warga yang ramah lingkungan, rasa kekeluargaan yang tinggi, saling membutuhkan satu sama lain tanpa paksaan dari berbagai pihak. Membantu keluarga yang membutuhkan bantuan untuk meringankan beban ketika warga sedang memiliki kebutuhan besar. Dalam setiap kegiatan warga sekitar antusias dalam mengikuti tradisi seperti: acara pernikahan, khitanan, kelahiran bayi, lelayu, membersihkan lingkungan desa, perbaikan jalan, renovasi masjid, dan terlibat dalam pembangunan Pondok Pesantren Al Falah.

Setiap masyarakat lokal mempunyai nilai-nilai khusus atau kearifan lokal yang bersumber dari budaya dan agama masyarakat setempat yang dimilikinya sendiri. Biasanya kearifan lokal tersebut dapat digunakan mereka untuk menjaga sistem budaya dan ekologi lingkungan mereka. Setiap komunitas atau desa akan menjalani kehidupan sesuai dengan tradisi adat istiadat dan kepercayaan, yang mengatur semua aspek kehidupan dan kegiatan mereka (Syamsul Ma'arif, 2015: 3132).

Adat istiadat terbentuk apabila tata kelakuan yang kekal serta kuat integrasinya dengan pola-pola perilaku masyarakatnya dan mempunyai kelakuan yang mengikat. Tradisi-tradisi yang masih dijalankan oleh masyarakat Gedongan yaitu memakai bahasa Jawa kromo halus dan tidak meninggalkan budaya Jawa atau tradisi Jawa. Selain itu, menurut salah satu warga bahwa kegiatan yang masih eksis di lingkungan masyarakat yaitu nguri-nguri kebudayaan Jawa seperti wayang, karawitan. Tingkat partisipasi masyarakat masih tinggi, mulai terorganisir setelah berdirinya Pondok Pesantren Al Falah karena sering mengadakan kegiatan pelatihan di lingkungan pondok (Wawancara dengan Ibu Sri Marsiti salah satu warga Gedongan, Baki Sukoharjo pada hari Ahad, 07 April 2019. Pukul 12:30 WIB).

B. Pertumbuhan Pondok Pesantren Al Falah 
Sebuah lembaga pendidikan tentunya membutuhkan sarana dan prasarana sebagai penunjang proses kegiatan belajar mengajar. Dengan demikian, diharapkan dapat meningkatkan fasilitas yang memadai dan tercapai sesuai visi, misi, tujuan pondok pesantren. Sarana dan prasarana di Pesantren Al Falah sebagai berikut:

1. Joglo

Bangunan ini milik pribadi ustadz Sri Setyo, digunakan untuk sarana tempat pendidikan para santri dan masyarakat umum. Pendidikan yang diajarkan oleh Ustadz Sri Setyo yaitu pendidikan al-Qur'an dan materi lain seperti, hukum Islam, akhlak tasawuf, sejarah, budaya dan aspek lain yang berkaitan dengan agama guna mempermudah pemahaman masyarakat terhadap agama Islam (Wawancara Abdullatif Nawasi (salah satu guru di Pesantren Al Falah), di ruang guru Pondok Pesantren Al Falah pada hari Senin, 14 April 2019 pukul 09.56 WIB).

2. Masjid

Masjid Pondok Pesantren Al Falah mengalami perpindahan sebanyak dua kali yaitu berdiri pada tahun 1990, berdiri di sebelah barat rumah joglo. Pada tahun 2002 tempat bergeser berada di sebelah barat bangunan masjid yang pertama. Pada tahun 2008 hingga tahun 2013 secara bertahap masjid diperluas karena semakin banyak santri yang belajar di Pondok Pesantren Al Falah.Masjid ini tidak hanya digunakan untuk sholat berjamaah saja, namun digunakan untuk kegiatan sosial keagamaan masyarakat (Wawancara Abdullatif Nawasi (salah satu guru di Pesantren Al Falah), di ruang guru Pondok Pesantren Al Falah pada hari Senin, 14 April 2019 pukul 09.56 WIB).

\section{Perpustakaan}

Pondok Pesantren Al Falah memiliki satu gedung perpustakaan berada di lantai dua, dibangun sejak awal berdirinya pondok pesantren. Fasilitas perpustakaan dengan staff perpustakaan yang akan mendampingi siswa dalam memenuhi kebutuhan referensi. Buku sebagai salah satu sumber ilmu tersedia di perpustkaan sekolah, baik buku akademik maupun non-akademik. Perpustakaan 
juga menyediakan beberapa koran, majalah, dan tabloid remaja ((Syamsul Ma'arif, 2015: 197).

\section{Asrama Putra}

Asrama putra berada di sebelah barat masjid, terdapat satu ruang besar sekitar 8x8 meter, sehingga banyak menampung santri yang bermukim di pesantren. Pada tahun 2008 hingga 2013, santri semakin banyak dan fasilitas perlu ditambahi oleh pihak pengurus berupa meja kursi untuk belajar para santri dan terdapat 15 kamar tidur bertingkat untuk tidur santri. Selain santri putra yang bermukim di pesatren, terdapat fasilitas penunjang lainnya seperti kamar mandi, tempat tidur, dapur, peralatan memasak, pendidikan, aturan yang harus ditaati, kegiatan rutinan setiap hari, setiap minggu dan setiap bulan. Dengan adanya fasilitas yang memadai maka terciptanya suasana yang kondusif tanpa ada halangan saat menjalankan kegiatan harian di lingkungan pondok pesantren.

\section{Sistem Pendidikan Formal}

Madrasah Tsanawiyah Satu Atap Pondok Pesantren Al Falah Gedongan didirikan pada tanggal 01 Mei 2009. Lokasi di Jl. Merpati No. 2A Dukuh Butuh RT. 03 RW. 02 Desa Gedongan Kecamatan Baki Kabupaten Sukoharjo, dengan luas tanah 2.332 $\mathrm{M}^{2}$. Madrasah Tsanawiyah Satu Atap Pondok Pesantren Al Falah merupakan sebuah lembaga pendidikan Islam yang setara dengan Pondok Pesantren Al Falah dengan sistem pendidikan terpadu.

Berdasarkan keputusan Kepala Kantor Wilayah Kementrian Agama Provinsi Jawa Tengah Nomor: Kw.11.4/4/PP.03.2/7653/2010 Tentang Persetujuan Pendirian Madrasah Tsanawiyah Swasta di Lingkungan Kantor Wilayah Kementerian Agama Provinsi Jawa Tengah resmi berdiri pada Tanggal 4 Oktober 2010. Setelah resmi berdiri, MTs Satu Atap Pondok Pesantren Al Falah mempunyai visi yaitu terwujudnya generasi sholeh/sholehah yang berakhlak, berprestasi Ilmu Pengetahuan dan Iman Taqwa, berwawasan global yang dilandasi nilai-nilai budaya luhur dan sesuai dengan ajaran Islam. 
Kurikulum Madrasah Tsanawiyah Satu Atap Pondok Pesantren Al Falah tahun 2009 hingga tahun 2013 yaitu menggunakan kurikulum dinas pendidikan dan kebudayaan, kementerian agama. Kurikulum dinas pendidikan dan kebudayaan menggunakan tingkat satuan pendidikan (KTSP). KTSP adalah kurikulum operasional yang disusun, dikembangkan dan dilaksanakan oleh setiap satuan pendidikan dengan memperhatikan standar kompetensi dan kompetensi dasar yang dikembangkan Badan Standar Nasional Pendidikan (BNSP). Sedangkan kurikulum kementerian agama terdiri dari mata pelajaran agama yaitu Alqur'an Hadits, Akidah Akhlak, Fiqih, Sejarah dan Kebudayaan Islam, Bahasa Arab

\section{Sistem Pendidikan Non Formal}

Wetonan : Istilah weton ini berasal dari kata wektu (Jawa) yang berarti waktu sebab pengajian tersebut diberikan pada waktu-waktu tertentu, yaitu sebelum dan atau sesudah melakukan shalat fardu. Metode Wetonan adalah metode di mana para santri mengikuti pelajaran dengan duduk di sekeliling kiai yang menerangkan pelajaran. Santri menyimak kitab masing-masing dan membuat catatan padanya (Marwan Saridjo, 1982: 32).

Sorogan : Adapun istilah sorogan tersebut berasal dari kata sorog (Jawa) yang berarti menyodorkan kitabnya di hadapan kiai atau pembantunya. Adapun metode sorogan ialah : santri menghadap kiai satu per satu dengan membawa kitab yang akan dipelajari. Kiai membacakan pelajaran berbahasa Arab itu kalimat demi kalimat kemudian menerjemahkannya, dan menerangkan maksudnya. Santri menyimak dan mengesahkan, dengan memberikan catatan pada kitabnya untuk mensahkan bahwa ilmu itu telah diberikan oleh kiai (Marwan Saridjo, 1982: 32-33).

Sistem pendidikan non formal Pondok Pesantren Al Falah juga menggunakan metode hafalan. Metode hafalan berlangsung dimana santri menghafal teks atau kalimat tertentu dari kitab yang dipelajarinya. Materi hafalan biasanya dalam bentuk syair atau nazham. Sebagai pelengkap, metode hafalan sangat efektif untuk memelihara daya ingat (memorizing) santri terhadap materi yang dipelajarinya, karena dapat diterapkan di dalam maupun diluar kelas (Sudadi, 2016: 174-175).

C. Perkembangan Pondok Pesantren Al Falah 
Pondok Pesantren Al Falah yang didirikan oleh Ustadz Sri Setyo berdiri di lingkungan masyarakat berkembang cukup pesat dalam segala hal aspek kehidupan. Pengembangan Pesantren Al Falah didasarkan pada kondisi masyarakat sekitar, yaitu terbatasnya kesempatan belajar yang ada. Pengembangan yang dilakukan dengan cara memberi akses kepada masyarakat terhadap pelayanan pendidikan yang terjangkau. Pada umumnya, pesantren tumbuh dan berkembang di desa-desa, maka kegiatan sosial pesantren didasari oleh usaha membangun desa yang bertujuan untuk meningkatkan taraf dan mutu kehidupan masyarakat desa. Corak desa yang dicita citakan pesantren adalah desa yang maju dan modern dengan fasilitas dan kesejahteraan hidup yang layak (Samsul Nizar, 2013: 199) Pengembangan pondok pesantren dilakukan secara bertahap, melalui bantuan dari masyarakat seperti gotongroyong, kerja bakti, tenaga dan biaya, bantuan dari pemerintah daerah sehingga mempercepat pembangunan fasilitas pondok dan siap digunakan untuk proses belajar mengajar.

Masjid di Pondok Pesantren Al Falah mengalami perkembangan yang cukup pesat setiap tahun. Pada tahun 2014 hingga 2018 dibangun sebanyak dua kali. Pertama tahun 2015 bergeser ke barat \pm 300 meter dari masjid yang sebelumnya berdiri. Selanjutnya, demi mewujudkan masjid yang makmur dan mengoptimalkan fungsinya, menjadi kewajiban bagi seluruh umat Islam. Karena, masjid adalah tempat yang suci bagi kaum (Wawancara Abdullatif Nawasi (salah satu guru di Pesantren Al Falah), di ruang guru Pondok Pesantren Al Falah pada hari Senin, 14 April 2019 pukul 09.56 WIB).

Pada tahun 2014 ketika mulai mengembangkan proses belajar melalui kebudayaan maka, ruang kesenian diperlebar guna menampung banyak santri dan masyarakat yang belajar di ruang tersebut. Setelah tahun 2015 sampai 2018 mulai mengembangkan fasilitas yang berada di ruang kesenian berupa tambahan alat peraga wayang, kelir dan alat penunjang lain yang berhubungan dengan kesenian karawitan dan wayang.

Kehadiran lembaga baru di lingkungan pesantren sebagai respon keadaan warga sekitar yang anak-anaknya tidak mampu melanjutkan sekolah ke jentang yang lebih tinggi, karena biaya pendidikan mahal karena kondisi ekonomi yang 
rendah. Lembaga ini berprinsip "lembaga pendidikan terjangkau tetapi bermutu". Kehadiran Pesantren Al Falah juga memberikan kemudahan kepada para santri yang tinggal di pesantren.11 Pondok Pesantren Al Falah dalam mengembangkan sistem pendidikan formal dibawah naungan Yayasan, dimulai pada tahun 2014 sampai 2018 mengembangkan dinamika satu pendidikan formal setara dengan pondok pesantren yaitu Madrasah Tsanawiyah Satu Atap Pondok Pesantren Al Falah.

Kurikulum Madrasah Tsanawiyah Satu Atap Pondok Pesantren Al Falah (MTs SA PP Al Falah) tahun 2014 hingga 2018 menerapkan sistem kurikulum 2013, mengikuti sistem kurikulum nasional yang diterapkan oleh pemerintah. Pada tahun 2015 pertama kali menerapkan kurikulum 2013 di kelas VII. Setelah itu secara bertahap tahun 2016 diterapkan kurikulum di kelas VIII dan tahun 2017 diterapkan di kelas IX dan seterusnya. Sampai saat ini kelas VII, VII, dan IX baru berjalan selama dua tahun yang menerapkan perkembangan kurikulum dari KTSP ke kurikulum 2013. Hal ini menunjukkan bahwa bertambahnya dengan adanya kurikulum baru tidak lepas dari peran guru dan prestasi santri tidak hanya tingkat kelurahan, kecamatan namun hingga kabupaten dan nasional.

Dalam masa perkembangan Pondok Pesantren Al Falah pada tahun 2014 hingga 2018. Ustadz Sri Setyo mengadakan perbaikan dalam sistem pendidikan dan pengajarannya. Langkah yang ditempuh adalah pembaruan sistem pendidikan lama ke sistem pendidikan baru, transformasi sistem tradisional ke sistem modern, akan tetapi, bukan menghapus sistem lama hanya mengembangkan saja dalam kurun waktu secara bertahap.

Sistem pendidikan menggunakan kitab klasik yaitu Riyadhus Shalikhin, sistem pendidikan ini diterapkan mulai awal berdirinya pondok pesantren. Santri belajar secara langsung oleh Kiai Sri Setyo apabila Kiai Sri Setyo berhalangan hadir maka digantikan oleh Bapak Latif atau tokoh lain yang akan mengisi. Kajian rutin dilakukan setiap hari ba'da sholat Maghrib hingga menjelang sholat Isya'. Setelah materi kitab tersebut selesai, maka diganti dengan kitab lain dan seterusnya. Dengan menerapkan metode tersebut maka ilmu pengetahuan santri dan masyarakat terus bertambah. Sistem pendidikan di Pondok Pesantren Al Falah juga 
menerapkan pada aktifnya sosial keagamaan dan budaya masyarakat. Kegiatan tersebut berupa baktisosial, pelatihan salat jenazah, hajaran, pengajian, Setelah santri lulus di pondok pesantren diharapkan dapat memimpin pengajian, ahlian, lawatan, kegiatan lain yang berkaitan dengan ilmu keagamaan, mampu menerapkan ilmunya dan bermanfaat bagi orang lain ((Wawancara Abdullatif Nawasi (salah satu guru di Pesantren Al Falah), di ruang guru Pondok Pesantren Al Falah pada hari Senin, 14 April 2019 pukul 09.56 WIB).

Berdasarkan hasil wawancara dengan Bapak Muh Fajar Syaifudin bawah perkembangan ekstrakurikuler karawitan cukup pesat karena kegiatan ini tidak hanya diikuti oleh santri saja namun masyarakat umum ikut andil dalam kegiatan ini. Kegiatan ini dilaksanakan setiap malam Jum'at di kompleks Pondok Pesantren Al Falah secara bergiliran setiap RT/RW dan Desa lainnya yang mengikuti kegiatan tersebut.

Tokoh yang memberikan materi kesenian jawa mampu memberikan sumbangan keilmuan dan menarik perhatian bagi masyarakat di sekitar pondok pesantren Al Falah dan di luar wilayah Dusun Gedongan. Selain itu sering mengadakan kegiatan di luar sekolah untuk tampil dalam acara tertentu seperti, kegiatan maulid Nabi, Isra' Mi'raj, Syawalan, dan tradisi Islam lainnya. Ekstrakurikuler kesenian karawitan di Pondok Pesantren Al Falah pada tahun 2014 sampai 2018 terbukti bahwa masyarakat yang berada di sekitar pondok pesantren tertarik dengan kesenian yang dikembangkan oleh pengurus pondok pesantren sebagai media dakwah Islam melalui wayang disertai dengan iringan gamelan.

\section{Simpulan}

Berdasarkan analisis yang dilakukan oleh peneliti tentang "Sejarah Pondok Pesantren Al Falah Gedongan, Baki, Sukoharjo, Jawa Tengah (2006- 2018)" dapat disimpulkan bahwa, Pondok Pesantren Al Falah merupakan pondok pesantren yang berbasis kebudayaan yang berada di wilayah Dusun Gedongan, Kecamatan Baki, Kabupaten Sukoharjo, Jawa Tengah. Sebelum berdirinya pondok pesantren ini, kondisi masyarakat sekitar pondok pesantren masih jauh dari aktifitas keagamaan seperti ibadah dan pengajian. Maka dari itu, Ustadz Sri Setyo ingin mendirikan 
sebuah yayasan untuk mengubah keadaan masyarakat menjadi taat aturan dan menjalankan ibadah dengan sebaik-baiknya.

Berdiri sebuah Yayasan Al Falah pada tahun 1999, mengubah segala aspek kehidupan masyarakat secara bertahap. Mengadakan kegiatan kajian rutin setiap malam Jum'at berupa kajian tauhid dan wayang dakwah. Selain itu, kerjasama dengan berbagai pihak untuk membangun relasi dengan lembaga di luar pondok pesantren, keinginan masyarakat untuk belajar lebih dalam materi keagamaan, tugas pengurus untuk mengadakan sebuah kegiatan yang menarik perhatian masyarakat. Pada tahun 2002 mendirikan Taman Pendidikan Al-Qur'an untuk membantu masyarakat mendalami pengetahuan agama dan menerapkan ke dalam kehidupan sehari-hari. Setelah berjalan selama empat tahun, maka keluarga Ustadz Sri Setyo mulai merintis pondok pesantren karena keinginan internal keluarga dan dukungan dari masyarakat di sekitar lingkungan rumah sehingga mendirikan sebuah pesantren.

Pondok Pesantren Al Falah diresmikan oleh Kementerian Agama Kabupaten Sukoharjo berdiri pada tahun 2006 dan berkembang dengan pesat sehingga mengubah pola kehidupan masyarakat dari tradisi abangan menjadi tradisi santri, dan hasil penelitian ini juga menunjukkan bahwa tradisi santri tersebut lambat laun berkembang menjadi tradisi sosial masyarakat setempat sehari-hari. Dimulai dari pembangunan gedung sekolah, tahap renovasi Masjid, mengembangkan sarana prasarana pondok pesantren, mendirikan sistem pendidikan formal, non formal dan ekstrakurikuler. Ketertarikan masyarakat untuk bergabung dengan Pondok Pesantren Al Falah yaitu berkaitan dengan kesenian yang dikembangkan oleh pengelola pondok pesantren. Berbeda dengan pondok pesantren yang lainnya, karena pondok pesantren ini berbasis kebudayaan yang dikembangkan melalui kegiatan kesenian karawitan dan wayang sebagai media dakwah. 


\section{DAFTAR PUSTAKA}

Dhofier, Zamakhsyari. Tradisi Pesantren: Studi tentang Pandangan Hidup Kyai. Jakarta: LP3ES, 1982.

Horton, Paul B dan Chester L Hunt, Sosiologi, Jakarta: Erlangga, 1996.

Kartodirdjo, Sartono. Pendekatan Ilmu Sosial Dalam Metodologi Sejarah. Jakarta: Gramedia Pustaka Utama. 1992.

Kuntowijoyo, Pengantar Ilmu Sejarah. Yogyakarta: Yayasan Benteng Budaya. 1995.

Ma'arif, Syamsul. Pesantren Inklusif: Berbasis Kearifan Lokal. Yogyakarta: Kaukaba Dibantara, 2015.

Madjid, Nurcholish. Bilik-bilik Pesantren Sebuah Potret Perjalanan. Jakarta: Paramadina, 1997.

Manfred Ziemek, Pesantren dalam Perubahan Sosial .Jakarta: Perhimpunan Pengembangan Pesantren dan Masyarakat (P3M), 1986.

Nizar, Samsul. Sejarah Sosial \& Dinamika Intelektual "Pendidikan Islam di Nusantara. Jakarta: Kencana Prenada Media Group, 2013.

Ranjabar, Jacobus. Sistem Sosial Budaya Indonesia: Sebuah Pengantar. Bandung: Alfabeta, 2013.

Saridjo, Marwan. Sejarah Pondok Pesantren di Indonesia. Jakarta: Dharma Bhakti, 1982.

Sudadi, Sejarah Pendidikan Islam di Indonesia. Yogyakarta: Pustaka Ilmu, 2016.

\section{Wawancara}

Bapak Fajar (salah satu guru di Pesantren Al Falah Gedongan Baki Sukoharjo), di rumah Bapak Fajar Bakipandeyan, Baki Sukoharjo pada hari Rabu tanggal 07 Maret 2019.

Ibu Sri Marsiti salah satu warga Gedongan, Baki Sukoharjo pada hari Ahad, 07 April 2019. Pukul 12:30 WIB.

Bapak Abdullatif Nawasi (salah satu guru di Pesantren Al Falah), di ruang guru Pondok Pesantren Al Falah pada hari Senin, 14 April 2019 pukul 09.56 WIB 